\title{
腰部脊柱管狭窄症における観血的治療の検討
}

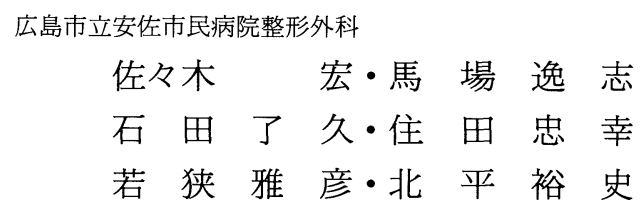

\section{Follow-up Study of Surgical Treatment for Lumbar Spinal Canal Stenosis}

by

\author{
Hiroshi Sasaki, Itsushi Baba, Akihisa Ishida \\ Tadayuki Sumida, Masahiko Wakasa and Hiroshi Kitahira \\ Department of Orthopedic Surgery, \\ Hiroshima City Asa Hospital
}

\begin{abstract}
A total of 46 patients with lumbar spinal canal stenosis were followed up, to evaluate the results of Surgical treatment. Thirty-two cases were degenerative type, 12 cases were combined type and 2 cases postoperative type. Eleven cases had unsatisfactory clinical results, which were suspected to have been caused by lumbar disc instability, complication of cervical spondylotic myelopathy, congenital anomaly of nerve roots, intraoperative injury of dura mata or cauda equina, hypertrophy of the articular facets and osteophyte formation of the posterior edge of the vertebral body.
\end{abstract}

\section{は じめに}

腰部脊柱管狭窄は, 1954 年 Verbiest ${ }^{4)} に よ り$ 報告さ れて以来数々の報告がある，今回われわれは，腰部春 柱管狭窄と診断し手術を行なった症例に対し検討した ので報告する。

\section{対 象}

昭和 55 年 5 月から昭和 61 年 12 月までに手術を施行 した 169 例中，今回直接検診を行なうことのできた degenerative type (degenerative spondylolisthesis を除く) 32 例, combined type 12 例, post operative type 2 例の計 46 例を対象とした. 性別は男性 25 例女 性 21 例, 手術時年令は 44 79 才, 平均 64.0 才である. 手術までの罹病期間は 2 力月〜 20 年，平均 3.7 年，術 後経過期間は 6 力月〜 6 年, 平均 2.7 年である (表 1 ).

方法

手術適応を決定する際にとくに職業，日常生活動作
を重視し保存的療法の効果のみられない症例に限り手 術を施行する。われわれは myelogram および myelo. 後 CT 像を参考とし初期の数例を除いては椎弓間開大 術を行なっているが，術中の状態により適宜除去範囲 を決定している。

\section{結 果}

術後成績は日整会腰痛治療成績判定基準(案，1984)

表 1 調査対象疾患

\begin{tabular}{|c|c|c|c|}
\hline \multicolumn{3}{|c|}{$\begin{array}{l}\text { degenerative } \\
\text { (degenerative spondylolisthesisを除く) } \\
\text { combined } \\
\text { post operative }\end{array}$} & $\begin{array}{r}32 \\
12 \\
2\end{array}$ \\
\hline \multicolumn{3}{|c|}{ total } & 46例 \\
\hline 性別 & 男性25例 & \multicolumn{2}{|c|}{ 女性21例 } \\
\hline $\begin{array}{l}\text { 手 術時年令 } \\
\text { 䍜 患 期 間 } \\
\text { 術後経過期間 }\end{array}$ & $\begin{array}{l}44 \sim 79 才 \\
2 \text { 力月〜20年 } \\
6 \text { 力月〜 6年 }\end{array}$ & \multicolumn{2}{|c|}{$\begin{array}{l}\text { (平均 } 64.0 \text { 才) } \\
\text { (平均 } 3.7 \text { 年) } \\
\text { (平均 } 2.7 \text { 年) }\end{array}$} \\
\hline
\end{tabular}



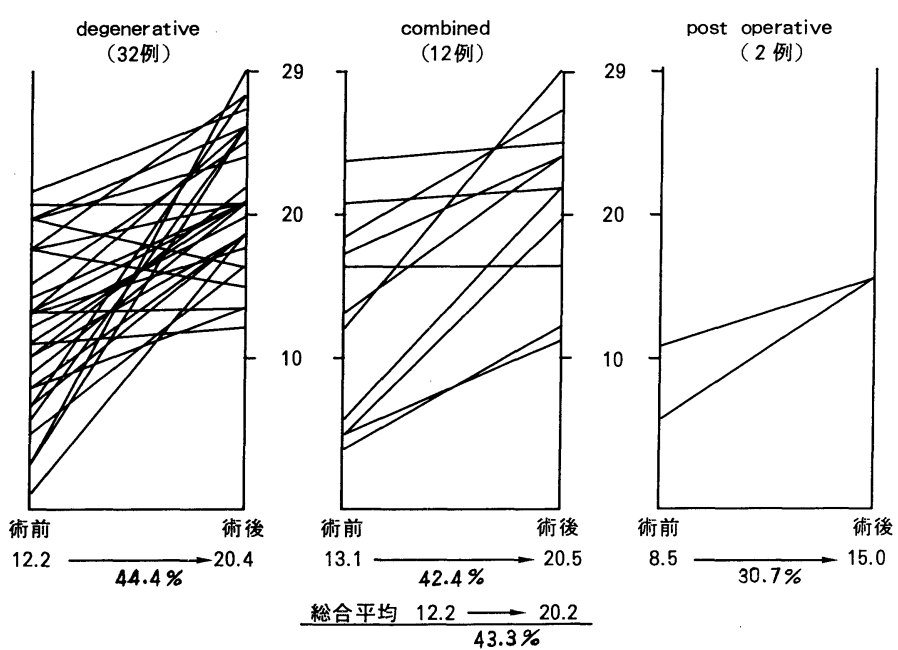

図 1 日整会腰痛疾患治療成績判定基準による評価

表 2 日整会腰痛治療成績判定基準（改善率\%)

\begin{tabular}{|c|c|c|}
\hline & 術後 3 年以上 & 術後 3 年末満 \\
\hline \multirow{5}{*}{$\begin{array}{l}\text { degenerative } \\
\text { combined } \\
\text { post operative }\end{array}$} & 41.3 & 46.7 \\
\hline & 28.7 & 47.0 \\
\hline & - & 30.7 \\
\hline & 39.1 & 46.0 \\
\hline & 65才以上 & 65才未満 \\
\hline \multirow{4}{*}{$\begin{array}{l}\text { degenerative } \\
\text { combined } \\
\text { post operative }\end{array}$} & 39.6 & 49.7 \\
\hline & 36.0 & 48.9 \\
\hline & 39.1 & 22.2 \\
\hline & 38.7 & 46.8 \\
\hline
\end{tabular}

表 3 術後成績不良例（改善率25\%未満）

\begin{tabular}{l|c}
\hline \hline degenerative & $32 \rightarrow 6$ \\
combined & $12 \rightarrow 4$ \\
post operative & $2 \rightarrow 1$ \\
\hline 計 & $46 \rightarrow 11$ 例 \\
\hline
\end{tabular}

に準じて, 自覚症状および他覚的所見から評価した. 総合点 29 点満点の判定基準では, 術前平均 12.2 点か ら術後 20.2 点に改善された. 各 type 別にみると degenerative type は 12.2 点から 20.4 点へ, combined type は 13.1 点から 20.5 点へ, post operative type は 8.5 点から 15.0 点へ改善された. 改善率で表わすと平均
$43.3 \%$ \%あり, degenerative type $44.4 \%$, combined type $42.4 \%$, post operative type $30.7 \%$ ある（図 1 ).

改善率を手術時年令が 65 才以上の高令者と 65 才未 満の者とを比較検討すると前者では平均 $38.7 \%$,後者 では $46.8 \%$ であり, 高令者の改善率は劣っていた。術 後経過年数が 3 年以上と 3 年末満の症例の改善率は, 前者より後者が勝っていた（表 2 ).

改善率が $25 \%$ 未満の術後成績不良 11 例については, degenerative type 6 例, combined type 4 例, post operative type 1 例であった（表 3 ).

成績不良例 2 例を供覧する。

症例 $1: 52$ 才, 女性.

変形性狭窄例である. 主訴は両下肢痛であり日整会 判定基準では術前 19 点であった. myelogram で $\mathrm{L}_{3 / 4,4 / 5}$ の不完全ブロックを呈し $\mathrm{L}_{4}$ の椎弓切除と $\mathrm{L}_{5}$ の部分椎 弓切除を施行した (図 $2-1$ ). 術後 5 年 6 力月の現在 $\mathrm{L}_{4}$ の过りをみとめ, 判定基準は 16 点, 改善率は一 $30 \%$ と悪化している（図 2-2）.

症例 $2: 65$ 才, 男性.

混合型狭窄例である。主訴は右下肢痛であり日整会 判定基準は術前 23 点であった. $\mathrm{X}$ 線像は $\mathrm{L}_{3 / 4,4 / 5}$ の椎間 不安定性と $\mathrm{L}_{4 / 5}$ の右側の椎間関節の肥大をみる. $\mathrm{L}_{4 / 5}$ 椎 弓間開大術と髄核摘出術を行ない, 術後 6 力月の現在 腰痛をみとめ判定基準は 24 点，改善率は $16.7 \%$ と思 わしくない. 


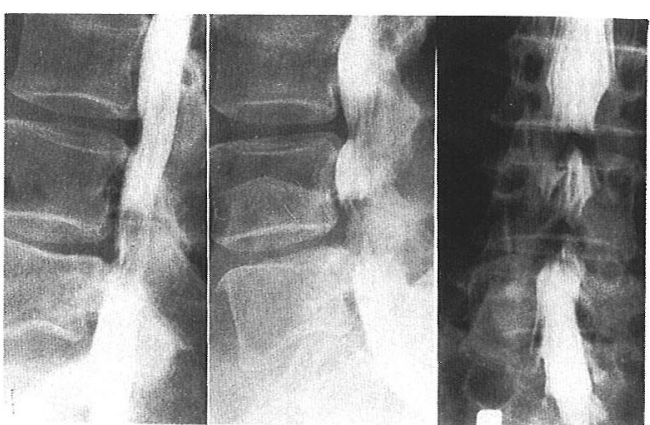

図 2-1 症例 1 術前 myelogram

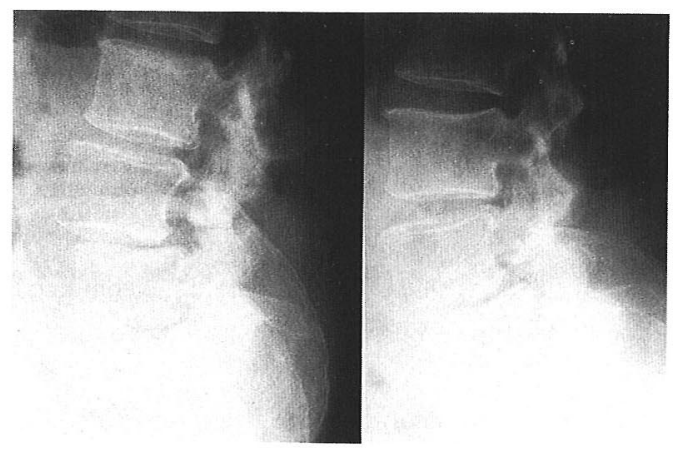

図 2-2 症例 1 術後 5 年 6 力月, $\mathrm{L}_{4}$ の过りをみと め。.

考察

今回, われわれの調査で 65 才以上の高令者の改善率 が劣っていた原因として，罹病期間が長く神経の非可 逆的変化が強いと考えられた。罹病期間と成績につい て,川井 ${ }^{2)} ら は$ 相関関係はみとめられなかったとしてい るが,われわれの症例では, 酒匂 ${ }^{3)}$ が述べているように 催病期間が長いほど成績の劣る傾向にあった。

術後経過期間が 3 年未満の症例は 3 年以上の症例に 対し改善率が高かった。これは combined type の術後 経過期間が 3 年以上のわれわれの症例では，他疾患を 合併したものが多く改善率が思わしくなく，これが全 体的な改善率の差として表われた。

改善率が $25 \%$ 末満の術後成績不良例中 combined type は 12 例中 4 例と高頻度にみとめられた。市原 ${ }^{1)}$ は combined type の不良例は比較的少ないと述べてお り，この理由として年令が比較的若く，障害部位が多 椎間にわたるものが少ないことをあげているが，われ われの症例でこのように高頻度にみとめられたのは， 比較的手術時年令が高く, 術後椎間関節の肥大をみと
表 4 成績不良因子

\begin{tabular}{|c|c|}
\hline \multicolumn{2}{|c|}{ 術前因子 } \\
\hline 1) & 椎間不安定性 \\
\hline 2) & 頝椎症性脊髄症の合併 \\
\hline 3) & 神経根の anomaly \\
\hline \multicolumn{2}{|c|}{ 術中因子 } \\
\hline 1) & 硬膜損傷 \\
\hline 2) & 馬尾神経損傷 \\
\hline \multicolumn{2}{|c|}{ 術後因子 } \\
\hline 1) & 椎間不安定性（过りを含む） \\
\hline 2) & 椎間関節の肥大 \\
\hline 3) & 椎体後縁骨棘の膨隆 \\
\hline
\end{tabular}

めるものが多いことが考えられた。

改善率 $25 \%$ 未満の予後不良例 11 症例について検討 すると, 術前因子として，1）椎間不安定性，2）頝椎 症性春髄症の合併，3)神経根の anomaly があげられ， 術中因子として，1）硬膜損傷，2）馬尾神経損傷があ り，術後因子として，1）椎間不安定性 (云りを含む)， 2）椎間関節の肥大，3）椎体後縁骨棘の膨隆があげら れる(表 4)。術後不安定性を生じた症例は多椎間にわ たる両側椎弓間開大術を行なった症例であり，过りが みとめられた症例は椎弓切除術を行なったものである。 術前より椎間不安定性をみとめた症例の改善率は思わ しくなく，後方除圧の際に何らかの固定が必要と思わ れた。最近われわれは，このような症例に対し棘突起 間を dexon 系を用いた補強を行なったり，椎間関節へ bone chip を移植し固定を行ない, 術後の不安定性の防 止に努めている。

われわれの症例では硬膜や馬尾神経の損傷を生じた 症例が 3 例含まれており，とくに post operative type の症例では micro下に atraumatic な操作が術後改善 率の向上につながると思われる。

\section{参 考 文 献}

1）市原健一・他：腰部脊柱管狭窄の手術療法に関する検 討。整形外科，37：196-202，1986.

2）川井和夫・他：腰部脊柱管狭窄症手術症例 185 例の検 討. 臨整外, $11: 708-726,1976$.

3）酒它 崇・他：腰部脊柱管狭窄の手術適応と術後成績 について. 整形外科, $32: 809-818,1981$.

4) Verbiest. H.: A radicular syndrome from developmental narrowing of the lumbal vertebral canal. J. Bone Joint Surg., 36-B : 230-237, 1954.

\section{質 問角田病院 角田 信肥}

長期 follow-up を考える場合，いろんな factor を考 慮しなければ，ならないのですが，その 1 つとして， 
各々の患者の経過中の変化も,重要かと思います.徐々 に変化するのか, プラトウーなのか，よくなって行く のか，そしてその時期はいつなのか，また，その間急 性の疼痛の経験しないのかなどであります．その点に 関して何か扔調べでしたら扔教え下さい.

解 答 広島市立安佐市民病院 佐々木 宏 術後 3 年頃より愁訴をみとめる症例が多いように思 われます。
質 問 鹿児島大学 酒匂 崇 術後不良因子として癒着性春髄膜炎の合併も考えら れるべきと考光る，先生の招示しになった成績不良症 例はそのような症例でないかと疑われるのですが，先 生の抢考えはいかがですか.

解答広島市立安佐市民病院 佐々木宏 瘾着性脊髄膜炎の合併も考えられる症例もあります が, 今回, 成績不良因子の中には含めておりません. 